\title{
Publisher Correction: All-inorganic cesium lead iodide perovskite solar cells with stabilized efficiency beyond $15 \%$
}

\author{
Kang Wang ${ }^{1}$, Zhiwen Jin ${ }^{1,2}$, Lei Liang ${ }^{1}$, Hui Bian¹, Dongliang Bai ${ }^{1}$, Haoran Wang ${ }^{1}$, \\ Jingru Zhang ${ }^{1}$, Qian Wang ${ }^{1,2} \&$ Shengzhong Liu ${ }^{1,3}$
}

Correction to: Nature Communications, https://doi.org/10.1038/s41467-018-06915-6; published online 31 October 2018

In the original version of this Article, the author name 'Shengzhong Liu' was incorrectly given as 'Liu Shengzhong'. This has been corrected in both the PDF and HTML versions of the Article.

Published online: 19 November 2018

\begin{abstract}
(c) (i) Open Access This article is licensed under a Creative Commons Attribution 4.0 International License, which permits use, sharing, adaptation, distribution and reproduction in any medium or format, as long as you give appropriate credit to the original author(s) and the source, provide a link to the Creative Commons license, and indicate if changes were made. The images or other third party material in this article are included in the article's Creative Commons license, unless indicated otherwise in a credit line to the material. If material is not included in the article's Creative Commons license and your intended use is not permitted by statutory regulation or exceeds the permitted use, you will need to obtain permission directly from the copyright holder. To view a copy of this license, visit http://creativecommons.org/licenses/by/4.0/.
\end{abstract}

(C) The Author(s) 2018

\footnotetext{
${ }^{1}$ Key Laboratory of Applied Surface and Colloid Chemistry, Ministry of Education, Shaanxi Key Laboratory for Advanced Energy Devices, Shaanxi Engineering Lab for Advanced Energy Technology, School of Materials Science \& Engineering, Shaanxi Normal University, 710119 Xi'an, People's Republic of China. ${ }^{2}$ School of Physical Science and Technology \& Key Laboratory for Magnetism and Magnetic Materials of MoE, Lanzhou University, Lanzhou 730000 , People's Republic of China. ${ }^{3}$ Dalian National Laboratory for Clean Energy, iChEM, Dalian Institute of Chemical Physics, Chinese Academy of Sciences, 116023 Dalian, People's Republic of China. Correspondence and requests for materials should be addressed to Z.J. (email: jinzhiwen@snnu.edu.cn) or to Q.W. (email: wangqian16@snnu.edu.cn) or to S.L. (email: szliu@dicp.ac.cn)
} 